Indonesian Journal of Nutrition and Dietetics Vol. 7, No. 2, 2019: 65-73
Available online at: http://ejournal.almaata.ac.id/index.php/IJND DOI : http://dx.doi.org/10.21927/ijnd.2019.7(2).65-73

\title{
Counseling of exclusive breastfeeding during antenatal care (ANC) and perceptions of insufficient milk supply
}

\author{
Eka Nurhayati ${ }^{1}$, Sandra Fikawati \\ ${ }^{1}$ Universitas Alma Ata Yogyakarta, Jalan Brawijaya No. 99 Tamantirto Bantul Yogyakarta \\ 2Universitas Indonesia, Pondok Cina, Kecamatan Beji, Kota Depok, Jawa Barat 12345 \\ *Corresponding author : eka890211@gmail.com
}

\begin{abstract}
ABSTRAK
Latar Belakang: Persepsi Ketidakcukupan ASI (PKA) adalah pikiran atau perasaan ibu terhadap kondisi ketiadaan atau berkurangnya produksi ASI sehingga ibu merasa bahwa ASI-nya tidak cukup untuk memenuhi kebutuhan bayinya. PKA menjadi alasan utama ibu berhenti menyusui secara dini dan alasan untuk memberikan makanan tambahan lebih awal pada bayinya. Prevalensi PKA belum diketahui secara pasti, diperkirakan antara 30-80\% dari ibu yang menyusui mempunyai PKA.

Tujuan : untuk mengetahui faktor paling dominan dalam PKA.

Metode: Desain penelitian ini menggunakan Cross Sectional. Jumlah sampel dalam penelitian ini sebanyak 71 sampel ibu yang memiliki bayi 0-6 bulan yang gagal menyusui secara eksklusif dikarenakan mengalami PKA.

Hasil: Hasil analisis didapatkan sebanyak 59 (83,1\%) ibu memiliki PKA dengan ASI yang cukup. Ada hubungan yang bermakna konseling ASI saat Antenatal Care (ANC) dengan PKA yang mempunyai ASI cukup, ibu yang tidak mendapatkan konseling saat ANC berpeluang 19, 7 kali mempunyai $P K A, p=0,012$; OR=19,746 (Cl 95\% 1,926-202,456).

Kesimpulan: Konseling ASI pada saat ANC yang berkualitas merupakan hal yang sangat penting dilaksanakan oleh petugas kesehatan untuk persiapan menyusui. Pemanfaatan "Temu wicara" dalam konsep 10 T dalam ANC perlu diefektifkan untuk membahas persiapan laktasi.
\end{abstract}

KATA KUNCI: persepsi ketidakcukupan ASI, konseling ASI

\begin{abstract}
Background: Perceptions of Insufficient Milk Supply (PIM) is the mother's thoughts or feelings about the condition of the absence or reduction in milk production. She felt that her breast milk is not enough to satisfy the needs of the baby. PIM was the main reason mothers stop breastfeeding early and a reason to give extra food early on the baby. Prevalence of PIM is not certain, it is estimated between $30-80 \%$ of breastfeeding mothers has PIM.

Objectives: This study aimed to find out the most dominant factors related to PIM.

Methods: Design of this study using cross-sectional. The numbers of samples in this study were 71 samples of mothers with babies' 0-6 months exclusive breastfeeding failure due to experiencing PIM.

Results: Found as many as 59 (83.1\%) mothers had PIM with enough milk. There is a significant correlation counseling exclusive breastfeeding during Antenatal Care (ANC) by PIM that has enough milk, mothers who did not receive counseling when the ANC likely to have 19.7 times PIM, $p=0.012 ;$ OR $=19.746$ (95\% Cl 1.926 to 202.456).

Conclusion: Exclusive Breastfeeding counseling during ANC quality does health personnel in preparation for breastfeeding implement a very important thing. Utilization of "Gathering of speech" in the concept of $10 \mathrm{~T}$ in the ANC should be effected to discuss preparation for lactation.
\end{abstract}

KEYWORDS: exclusive breastfeeding, perceptions of insufficient milk supply 


\section{INTRODUCTION}

Breastfeeding is practiced in various levels of society all around the world because of many benefits obtained from exclusive breastfeeding. In 2006 WHO (World Health Organization), set the standard of children's growth is the importance of exclusive breastfeeding since the baby birth up to six months (1). After that additional food was given while breastfeeding is also given up to 2 years. Data bank global of WHO about infant and Young Child Feeding (IYCF) show that the number of mothers giving exclusive breastfeeding for less than 4-month decrease from $55.1 \%$ in $2002-2003$ to $40.6 \%$ in 2007-2008, while the number of mothers giving exclusive breastfeeding for less than does month show the decrease from $39.5 \%$ IN 2002-2003 TO 32.4 IN 2007-2008 (2). Data of Riskesdas 2013 shows the breastmilk coverage in Indonesia was $42 \%$ less than the target of $\mathrm{WHO}$ as $50 \%$ (3).

The frequent problem in early stage of lactation is that the wound at the nipple, breast is swollen, breast milk is clogged up; breast milk stream is not smooth. The success of breast feeding early postpartum will affect exclusive breastfeeding. The mother who cannot solve the problem in the early weeks of post partum will stop breastfeeding (4). The factors affecting mother in exclusive breastfeeding are the mother's perception of breast milk inadequacy (PIM). Breast milk production is a biological process affected by reflects the movement of baby sucking. Breastmilk inadequacy is only an abnormal pathology case or lack of stimulation in the breast. Mother perception about breast milk inadequacy produced can make a mother stop doing breastfeeding. PIM occurs if the mother gives exclusive breastfeeding with the reason for having no breastmilk (5).

At this time, the coverage of babies who were exclusively breastfed in Bantul District in 2013 was $62.05 \%$ and in 2012 it was $63.51 \%$. One area with a low ratio is the working area of Sewon Health Center, the scope of exclusive breastfeeding at the Sewon Health Center in 2012 was the lowest in Bantul District, which was $23.7 \%$ (Sewon I) and $58 \%$ (Sewon II), and these numbers are far from the target of the strategic plan of Bantul s $80 \%$ (6).
One of the contributing factors is PIM. Therefore, researchers aim to find out the dominant factors affecting PIM in mothers who have babies aged 0-6 months in the working area of Pukesmas Sewon Yogyakarta.

\section{MATERIALS AND METHODS}

This research is quantitative research. The research design used in this study was a crosssectional design. This research was conducted in 2015 in the working area of primary health care, Sewon, Yogyakarta. This study consists of several independent variables, namely maternal factors, infant factors and lactation factors and one dependent variable, namely the Perceptions of Insufficient Milk Supply. The sample in this study was 71 mothers who had infants aged 0-6 months who failed in giving exclusive breastfeeding with a maximum time of 2 weeks at the time of the study.

PIM is determined by questions about the reason for mothers to stop breastfeeding exclusively. If the reason is because the milk is not enough to fulfill the needs of the baby but the weight gain was $>500$ grams/month and urination more than 6 times a day, so that the mother is considered to experience PIM with adequate breast milk, whereas if the reasons is because the milk is not enough to fulfill the needs of the baby but the weight gain was $\leq 500$ grams/month and urinate 6 times a day, so mothers are considered to experience PIM with inadequate milk.

The nutritional status of the mother is seen from the weight gain of the mother during pregnancy, is it in accordance with the recommendations of the Institute of Medicine (IOM). The suitability of weight gain is based on the maternal pre-pregnancy BMI obtained by the Achadi estimation formula (7). Data on maternal weight during pregnancy are obtained from the Mother and Child Health $(\mathrm{MCH})$ book. Information on age, parity, occupation, antenatal care (ANC) breastfeeding, knowledge about exclusive breastfeeding, knowledge about growth spurt, maternal support groups, family support, contraception, birth weight and the practice of Early Breastfeeding Initiation were obtained through interviews using a structured questionnaire. 
The statistical test in this study is univariate which is used to determine the frequency distribution of each variable, bivariate was conducted by using chi-square to find out the variables associated with PIM and multivariate tests using multiple logistic regression prediction models to find out the most dominant variables related to PIM.

\section{RESULTS}

The percentage of PIM with adequate breast milk in Puskesmas Sewon Bantul Yogyakarta was $83.1 \%$ (Table 1). Most respondents were $\leq 30$ years old $(68 \%)$ and almost all respondents had a parity of $1-2$ children (85.9\%). In the case of work, some respondents did not work (66.2\%). Maternal nutritional status measured by pre-pregnancy $\mathrm{BMI}$ and maternal weight gain during pregnancy indicated that many women have gained weight in accordance with the recommendations (62\%). There are still many respondents who lack of knowledge $(67.6 \%)$ and many respondents who do not receive exclusive breastfeeding counseling during ANC $(59.2 \%)$. Almost all respondents did not follow the maternal support group (98.6\%) and also did not know about growth spurt (95.8\%). Most respondents used non hormonal contraception (56.3\%) and lack of family support (53.5\%). Respondents who did not practice Early Breastfeeding Initiation were (77.5\%) and those who had babies with normal birth weight were $(94.4 \%)$.

Bivariate analysis showed that the variables associated with PIM were knowledge of exclusive breastfeeding with $p=0.014$, breastfeeding counseling when ANC with $p=0,000$, weight gain during pregnancy with $p=0.047$ and Practice of Early Breastfeeding Initiation with $p=0.003$ (Table 2)

Furthermore, multivariate analysis showed that the variable of breast milk counseling during ANC and Practice of Early Breastfeeding Initiation significantly correlated with PIM after being controlled for family support variables, knowledge of exclusive breastfeeding and weight gain during pregnancy. Breast milk counseling when ANC is the most dominant factor associated with PIM (Table 3).
Table 1. Results of Univariate Analysis

\begin{tabular}{|c|c|c|}
\hline Variable & $\mathbf{n}$ & $\%$ \\
\hline \multicolumn{3}{|c|}{ Perceptions of insufficient Milk Supply (PIM) } \\
\hline PIM with inadequate breast milk & 12 & 16.9 \\
\hline PIM with adequate breast milk & 59 & 83.1 \\
\hline \multicolumn{3}{|l|}{ Mother's age } \\
\hline$\leq 30$ Years old & 49 & 69.0 \\
\hline$>30$ Years old & 22 & 31.0 \\
\hline \multicolumn{3}{|l|}{ Parity } \\
\hline 1-2 children & 61 & 85.9 \\
\hline$\geq 3$ children & 10 & 14.1 \\
\hline \multicolumn{3}{|l|}{ Occupation } \\
\hline work & 24 & 33.8 \\
\hline do not work & 47 & 66.2 \\
\hline \multicolumn{3}{|l|}{ Weight gain during pregnancy } \\
\hline In accordance with recomendation & 44 & 62.0 \\
\hline $\begin{array}{l}\text { Not In accordance with } \\
\text { recomendation }\end{array}$ & 27 & 38.0 \\
\hline \multicolumn{3}{|l|}{ Counseling of ANC } \\
\hline Do not get & 42 & 59.2 \\
\hline Get & 29 & 40.8 \\
\hline \multicolumn{3}{|l|}{ Maternal supporting Group } \\
\hline Non member & 1 & 1.4 \\
\hline Member & 70 & 98.6 \\
\hline \multicolumn{3}{|l|}{$\begin{array}{l}\text { Knowledge about exclusive } \\
\text { breastfeeding }\end{array}$} \\
\hline Low & 48 & 67.6 \\
\hline Good & 23 & 32.4 \\
\hline \multicolumn{3}{|l|}{ Knowledge of Growth Spurt } \\
\hline Do not know & 68 & 95.8 \\
\hline Know & 3 & 4.2 \\
\hline \multicolumn{3}{|l|}{ Contraseption } \\
\hline Hormonal & 31 & 43.7 \\
\hline Non Hormonal & 40 & 56.3 \\
\hline \multicolumn{3}{|l|}{ Family support } \\
\hline No & 38 & 53.5 \\
\hline Yes & 33 & 46.5 \\
\hline \multicolumn{3}{|l|}{ Birth weight } \\
\hline Low birth weight & 4 & 5.6 \\
\hline Normal & 67 & 94.4 \\
\hline \multicolumn{3}{|l|}{ Early Breastfeeding Initiation } \\
\hline Not Early Breastfeeding Initiation & 55 & 77.5 \\
\hline Early Breastfeeding Initiation & 16 & 22.5 \\
\hline
\end{tabular}

\section{DISCUSSION}

Based on the results of the study showed that $72 \%$ have PIM with sufficient breast milk, while mothers who have PIM with less breast milk are $12(16.9 \%)$. According to Gatti (8), the majority of mothers who had PIM as the main problem of 
Table 2. Bivariate result of factors associated with Perceptions of Insufficient Milk Supply

\begin{tabular}{|c|c|c|c|c|c|c|c|c|}
\hline \multirow{3}{*}{ Variables } & \multicolumn{4}{|c|}{ Perceptions of insufficient milk supply } & & & \multirow{3}{*}{ Pvalue } & \multirow{3}{*}{$\begin{array}{c}\text { OR } \\
\text { (Cl 95\%) }\end{array}$} \\
\hline & \multicolumn{2}{|c|}{$\begin{array}{c}\text { Adequate Breast } \\
\text { Milk }\end{array}$} & \multicolumn{2}{|c|}{$\begin{array}{l}\text { Inadequate breas } \\
\text { milk }\end{array}$} & \multicolumn{2}{|c|}{ Total } & & \\
\hline & $\mathbf{n}$ & $\%$ & $\mathbf{n}$ & $\%$ & $\mathbf{N}$ & $\%$ & & \\
\hline \multicolumn{9}{|l|}{ Mother's age } \\
\hline$\leq 30$ Years old & 40 & 81.6 & 9 & 18.4 & 49 & 100 & \multirow[t]{2}{*}{0.724} & 0.702 \\
\hline$>30$ Years old & 19 & 86.4 & 3 & 13.6 & 22 & 100 & & $(0.17-2.892)$ \\
\hline \multicolumn{9}{|l|}{ Parity } \\
\hline 1-2 child(ren) & 51 & 83.6 & 10 & 16.4 & 61 & 100 & \multirow[t]{2}{*}{0.673} & 1.275 \\
\hline$\geq 3$ children & 8 & 80.0 & 2 & 20.0 & 10 & 100 & & $(0.235-6.919)$ \\
\hline \multicolumn{9}{|l|}{ Occupation } \\
\hline work & 20 & 83.3 & 4 & 16.7 & 24 & 100 & \multirow[t]{2}{*}{1,000} & 1.026 \\
\hline do not work & 39 & 83 & 8 & 17.0 & 47 & 100 & & $(0.275-3.823)$ \\
\hline \multicolumn{9}{|c|}{ Weight gain during pregnancy } \\
\hline $\begin{array}{l}\text { In accordance with } \\
\text { recomendation }\end{array}$ & 40 & 90.9 & 4 & 9.1 & 44 & 100 & \multirow[t]{2}{*}{$0.047^{*}$} & 4.211 \\
\hline $\begin{array}{l}\text { Not In accordance } \\
\text { with recomendation }\end{array}$ & 19 & 70.4 & 8 & 29.6 & 27 & 100 & & $(1.126-15.740)$ \\
\hline \multicolumn{9}{|l|}{ Counseling of ANC } \\
\hline Do not get & 41 & 97.6 & 1 & 2.4 & 42 & 100 & \multirow[t]{2}{*}{$0.000^{*}$} & 25.056 \\
\hline Get & 18 & 62.1 & 11 & 37.9 & 29 & 100 & & $(3.005-208.9)$ \\
\hline \multicolumn{9}{|c|}{ Knowledge about exclusive breastfeeding } \\
\hline Low & 44 & 91.7 & 4 & 8.3 & 48 & 100 & \multirow[t]{2}{*}{$0.014^{*}$} & 5.867 \\
\hline good & 15 & 65.2 & 8 & 34.8 & 23 & 100 & & $(1.543-22.308)$ \\
\hline \multicolumn{9}{|c|}{ Knowledge of Growth Spurt } \\
\hline $\begin{array}{l}\text { Do not know } \\
\text { Good }\end{array}$ & 56 & 82.4 & 12 & 17.6 & 68 & 100 & \multirow[t]{2}{*}{1.000} & 0.824 \\
\hline Know & 3 & 100 & 0 & 0 & 3 & 100 & & $(0.738-0.919)$ \\
\hline \multicolumn{9}{|l|}{ Contraseption } \\
\hline Hormonal & 24 & 77.4 & 7 & 22.6 & 31 & 100 & \multirow[t]{2}{*}{0.421} & 0.490 \\
\hline Non Hormonal & 35 & 87.5 & 5 & 12.5 & 40 & 100 & & $(0.139-1.726)$ \\
\hline \multicolumn{9}{|l|}{ Family support } \\
\hline No & 35 & 92.1 & 3 & 7.9 & 38 & 100 & \multirow[t]{2}{*}{0.064} & 4.375 \\
\hline Yes & 24 & 72.7 & 9 & 27.3 & 33 & 100 & & $(1.072-17.850)$ \\
\hline \multicolumn{9}{|l|}{ Birth weight } \\
\hline Low birth weight & 4 & 100 & 0 & 0 & 4 & 100 & 1.000 & 1.18 \\
\hline Normal & 55 & 82.1 & 12 & 17.9 & 67 & 100 & & $(1.089-1.62)$ \\
\hline $\begin{array}{l}\text { Early Breastfeeding Init } \\
\text { Not Early } \\
\text { Breastfeeding }\end{array}$ & ation & & & & & & & \\
\hline Initiation & 50 & 90.9 & 5 & 9.1 & 55 & 100 & $0.003^{*}$ & 7.778 \\
\hline Early Breastfeeding & & & & & & & & \\
\hline Initiation & 9 & 56.2 & 7 & 43.8 & 16 & 100 & & $(2.018-29.983)$ \\
\hline
\end{tabular}

Table 3. Logistic Regression Perceptions of Insufficient Milk Supply

\begin{tabular}{lcccc}
\hline \multicolumn{1}{c}{ Variable } & B & p-value & OR & 95\% Cl \\
\hline Counseling of exclusive breastfeeding during ANC & 2.054 & $0.012^{*}$ & 19.746 & $(1.926-202.456)$ \\
Knowledge about exclusive breastfeeding & 1.210 & 0.181 & 3.354 & $(0.569-19.779)$ \\
Practice of early breastfeeding initiation & 2.054 & $0.027^{\star}$ & 7.803 & $(1.266-48.107)$ \\
Family support & 0.801 & 0.373 & 2.227 & $(0.383-12.946)$ \\
Weight gain during pregnancy & -0.827 & 0.366 & 0.437 & $(0.073-2.626)$ \\
\hline
\end{tabular}


breastfeeding and it is the main reason for mothers to stop exclusive breastfeeding. The percentage of PIM in the world ranges at $30-80 \%$. Mothers who experience PIM with sufficient milk can be said that the mother is in Weanling's dilemma (9)growth, and development, and on maternal health, of exclusive breastfeeding for 6 months vs exclusive breastfeeding for 34 months with mixed breastfeeding (introduction of complementary liquid or solid foods with continued breastfeeding, which means the mother's belief that breast milk alone is not enough for her baby's nutritional needs so the mother adds food or beverage other than breast milk due to insufficient nutrition occurs when the baby reaches the age after 3-4 months. In this study, it was also seen that the average mother stopped breastfeeding exclusively when the baby was over 3 months old. Some of the reasons are their breast milk began to decrease, the baby cried because of hunger and the baby was not satisfied to suck so that the mother gave additional nutrition besidesbreast milk. Whereas mothers who experience PIM with less breast milk as many as 12 people (16.9\%) and 8 of them experienced weight gain during pregnancy not according to recommendations. Weight gain is an indicator of the nutritional status of mothers, so mothers with less nutritional status need more energy to produce milk.

This study is different from other studies because in this study PIM has been clarified, whether PIM is followed by sufficient breast milk or insufficient breast milk. By having a clearer conditions of the adequacy of breast milk which follows PIM, it can be said whether the PIM is only the perception of the mother or it is true that breast milk is inadequate. Other PIM studies did not look at PIM incomplete cases because it is possible that PIM happens more because of the mother's perception, and it was not because of the actual condition. Although it could be due to the bad maternal nutritional status, then breast milk was also reduced so that PIM had more tendencies to be felt by mothers.

Mother's age is defined as the respondent's age which is calculated based on the last birthday with a standard age of 30 years. From the results of the bivariate statistical test with $p$-value $=0.724$ which means there is no significant correlation between age and PIM. This study is not in accordance with the results of the Komalasari study which found a significant correlation between age and PIM with $p$-value $=0.00010$. In contrast, Young mothers have an unfavorable tendency to produce breast milk for various reasons. Their own nutritional status before pregnancy is often inadequate, pregnancy is full of tension, and the demands and social pressures after childbirth are all against the proper formation and maintenance of breastfeeding. The results of research on parity also show that a p-value of 0.673 is obtained, which means there is no significant correlation between parity and PIM. This study is in line with Trisnawati which states that there is no significant correlation between parity and PIM, with a value of $p=0.902(10)$.

Based on the results of bivariate analysis, work does not relate to PIM with a p-value of 1,000 . This is not in accordance with that there is a significant correlation between work and PIM with $p$-value $=0.029$ (11). Working mothers tend to have PIM because these working mothers consider it more practical and more "capable". After all, they already have more income in the family to be able to buy and provide formulated milk than to do breastfeeding. It was emphasized with time limitations. The day off regulation for pregnant women and giving birth for working mothers last only for 3 months. Actually, working mothers can also provide exclusive breastfeeding, but in practice, it turns out to be difficult to apply because it is hampered by various parties so that the conditions do not allow them to provide exclusive breastfeeding. This statement was emphasized in the analysis of the implementation of the study and the policy of Exclusive breast milk and early breastfeeding initiation in Indonesia that labor regulations (Labor Law No.13 / 2003 Article 81), the length of maternity and maternity leave only 3 months. The length of maternity and maternity leave stated in the regulation is certainly not sufficient for the implementation of 6-month exclusive breastfeeding unless facilitated with instruments (12).

From the results of the statistical tests in the bivariate analysis, the p-value of 0.047 obtained using an alpha of $5 \%(0.05)$ can be concluded that 
there is a significant correlation between weight gain during pregnancy and PIM. Weight gain during pregnancy is an indicator of determining the nutritional status of the mother. If the mother's weight at the first antenatal visit was $<47 \mathrm{~kg}$, then the likelihood of giving birth to a LBW baby is 1.73 times greater than that of a mother whose body weight was $\geq 47 \mathrm{~kg}$ and gain weight for $<21$ grams/ week will present a risk of giving birth to LBW 1.85 times greater when compared to women who gain weight $\geq 21$ grams/week (13). PIM is affected by nutritional status during pregnancy less than the recommendation. This is in accordance with the research that mothers who do breastfeeding with poor nutritional status have a risk of 2.24-2.34 times for failing to breastfeed for 4 months compared to mothers with normal nutritional status. One effect of breastfeeding can also reduce the recommended weight of $2 \mathrm{~kg} /$ month. If during pregnancy the nutritional status was low, it will also affect milk production during breastfeeding (14).

The study of the Kac $\mathrm{G}$ et al. In Brazil proved that postpartum weight retention was more reduced in mothers with low-fat percentage compared with a high fat percentage which is $3 \mathrm{~kg}$ at $18 \%$ fat and 0.04 $\mathrm{kg}$ at mothers with $35 \%$ fat percent (15). This shows the use of maternal energy to produce milk. Even seen mothers with less nutritional status require more energy to produce milk. It was even seen that mothers with poor nutritional status require more energy to continue breastfeeding. Allegedly at the stage of maternal nutritional status can no longer support the formation of the breast milk process, mothers will choose to provide additional food to their babies.

The results of the univariate analysis of maternal support groups revealed that almost all mothers $(70.6 \%)$ stated that they did not participate in the maternal support group. In this study, the maternal support group in the working area of the Sewon health center was a vacuum of more than one year due to several obstacles, including the difficulty of finding the right time for a mother's KP meeting, the lack of motivators, lack of funds for the provision of supplementary feeding. In fact, in one hamlet some of them included the material of the mother's support group in the routine meeting of the neighborhood association, so it was natural for mothers who had babies aged 0-6 months to be almost not participating in the maternal support group.

The knowledge variable consists of six basic questions about Exclusive breast milk those are the definition of Exclusive breastfeeding, the best food or drink that is first given to infants, things to do with colostrum, administration of other food or drinks before the breast milk produced, when complementary feeding is given, and the benefits of Exclusive breastfeeding. Bivariate statistical test results show that there was a significant correlation between knowledge and PIM with $\mathrm{p}$-value $=0.014$ and it can be seen that mothers who had lack exclusive breastfeeding knowledge are more likely to experience PIM with adequate breast milk compared to mothers who have good knowledge. In multivariate analysis, there was no significant correlation between exclusive breastfeeding knowledge and PIM with $p$-value $=0.181$. The results of this study are not in line with research shows that there was a significant correlation between knowledge about exclusive breastfeeding and PIM with $p$-value $=0.00818$ (16)Kota Tegal tahun 2014. Penelitian ini merupakan penelitian primer dengan desain studi potong lintang. Sampel berjumlah 88 ibu dari bayi berusia 0 - 6 bulan yang dipilih secara purposive sampling. Status gizi ibu dilihat dari kenaikan berat badan ibu sewaktu hamil apakah sesuai dengan rekomendasi dari Institute of Medicine. Asupan energi ibu saat laktasi diukur melalui wawancara dengan menggunakan semiquantitative-Food Frequency Questionnaire (FFQ / Food Amount Questionnaire (FAQ.

The results of the bivariate analysis of the correlation between knowledge of Growth Spurt and PIM note that there was no significant correlation between knowledge of Growth Spurt and PIM, with a p-value of 1,000 . It shows that the term Growth Spurt is a new thing and it has not known yet by the community in Sewon primary Health Care, Bantul District. After the researchers asked the respondent whether they experienced a growth spurt, many respondents experienced that period, but indeed 
almost all respondents did not know about it. Even many health workers who were there did not know the term, for this reason, there was a need for socialization on Growth Spurt involving Maternal health and child and Health promotion.

Bivariate statistical test results revealed that there was no significant correlation between hormonal contraception with a p-value of 0.421 . The results of this study are consistent with the research of the study found a small proportion $(55.6 \%)$ of mothers using estrogen-containing contraception, and the majority (68.3) of mothers using contraceptives that do not contain estrogen, nonhormonal, and not having a family planning program who had PIM (17). After analysis, it was stated that there was no significant correlation between contraception and PIM with $p=0.419$. The results of the bivariate analysis of the correlation of family support with PIM also found that there was no significant correlation between family support and PIM with a $p$-value of 0.054 .

The results of the bivariate analysis of the correlation between newborn baby and PIM revealed that there was no significant correlation between newborn baby and PIM with a p-value of 1,000 . Another theory suggests that babies born with very low birth weight may still be too weak to suck breast milk from their mother's breast (18). Then it is reinforced by the statements that namely low birth weight babies (LBW) have problems in breastfeeding because the ability to suck breast milk is lower than babies with normal birth weight $(>2500$ grams) (19). The ability to suck breast milk is lower include the frequency and duration of breastfeeding is lower than normal birth weight babies which will affect the stimulation of the hormone prolactin and oxytocin in producing milk.

Bivariate anylisis results indicate a tendency that the proportion of PIM with breast milk is more experienced by mothers who do not implement early breastfeeding initiation compared to mothers who carry out early breastfeeding initiation. Multivariate statistical test results obtained $p$-value of 0,027 using a $5 \%(0.05)$ alpha can be concluded that there was a significant correlation between the practice of early breastfeeding initiation and PIM. with a POR value of $7.803(95 \% \mathrm{Cl}: 1,266-48,107)$ which means that mothers who do not practice early breastfeeding initiation have a 7.8 times greater chance for PIM compared to mothers who do early breastfeeding initiation. Research shows that mothers who are immediate breastfeeding are 2 to 8 times more likely to breastfeed exclusively for up to 4 months compared to women who are not immediate breastfeeding. Immediate breastfeeding, the mother will be more confident to give her breast milk so that there is no need to give food or drink to the baby because the baby can be comfortably attached to the breast or calm in the mother's arms immediately after birth (20).

The early breastfeeding initiation steps are not yet well known to health workers. The early breastfeeding initiation step in this study stopped a lot when the baby phase had not yet reached breastfeeding or had succeeded in breastfeeding but not until 1 hour because the average early breastfeeding initiation was done within 10-30 minutes. The baby is placed on the mother's breast only until the stitching process is completed and then brought to the baby's room for mothers who give birth normally or with help. Whereas for mothers who give birth with a cesarean process, none of them in the early breastfeeding initiation is because there is special monitoring so that the baby does not experience respiratory failure or other problems. in contrast according to the understanding of breast crawl according to every newborn that is placed on his mother's abdomen soon after birth has the ability to find the breast of a mother and decide when to take her first breast milk.

In a collection of articles on breast crawl, it shows that immediately after birth in infants placed on the breast of the mother, after being observed for 15 minutes the baby sucks spontaneously and rooting movements occur with reaching maximum intensity at 45 minutes. With the first hand-to-mouth movements after being observed on average at 34 minutes after birth and at 55 minutes babies find nipples and spontaneously start breastfeeding. These findings indicate that feeding behavior in the early stages of infant development during the first hour of life, initially only spontaneous sucking 
and rooting movements followed by hand-to-mouth movements, together with more frequent sucking intensity and rooting movements and the peak is breast sucking (21)

The dominant factor associated with PIM is breastfeeding counseling during ANC. Mothers who did not receive breast milk counseling during ANC had a 19.7 times greater chance of PIM compared to mothers who received breast milk counseling during ANC. Information obtained by respondents regarding breastfeeding from midwives or health workers during ANC visits is one of the preparations for breastfeeding during pregnancy and it is important because with good preparation the mother is better prepared to breastfeed her baby. This study is in accordance with the research that there was a significant correlation between prenatal lactation guidance and PIM $p$-value $=0.05$. From the statistical test results, it was also found that the value of $\mathrm{OR}=3.48$ means that respondents who did not receive prenatal lactation guidance had a 3.5 times chance of PIM (17).

Information and support for mothers and their families must be provided during pregnancy. Preparation for breastfeeding during pregnancy is important because with better preparation the mother is better prepared to breastfeed her baby. Therefore pregnant women should be included in the "Nursing Preparation Guidance" class. Prenatal lactation guidance is the basis of breastfeeding success (22). Conditions in the field showed that many mothers did not receive breastfeeding counseling during ANC, especially those who examined their pregnancies at the obstetrician, while those who received the most counseling when the mothers checked their pregnancies at the Independent Practice Midwife. Counseling at ANC at the Sewon Health Center has not been routinely held. This was conveyed by several mothers who had received 1time of counseling about breast milk when ANC was done in groups or together.

Provision of information through print media such as leaflets, pamphlets, and booklets has also not been utilized by primary health care or nursing preparation guidance class, because almost all respondents have never received leaflets, pamphlets or booklets containing advice on breastfeeding. As a matter of fact, printed media is an effective means of disseminating information because it can be carried anytime and can be read anywhere. In a qualitative study, it was seen that when Antenatal Care was not widely used by health workers to provide information about exclusive breastfeeding to mothers, so mothers did not give their milk exclusively. This study states and suggests that mother's knowledge plays an important role in the implementation of exclusive breastfeeding so that efforts to increase knowledge must be carried out before giving birth because it is too late if done after giving birth (23).

\section{CONCLUSIONS AND RECOMMENDATION}

The incidence of PIM with adequate breast milk in the working area of the Sewom Bantul Primary Health Care in Yogyakarta was 59 (83.1\%). In the bivariate analysis variables related to PIM were breast milk counseling during ANC, early breastfeeding initiation practices, weight gain during pregnancy, knowledge of exclusive breastfeeding. In multivariate analysis there were two variables that have a significant correlation, those were the practice of early breastfeeding initiation and exclusive breastfeeding counseling during ANC. The most dominant factor was breastfeeding counseling during ANC is controlled by family support, knowledge about exclusive breastfeeding and weight gain during pregnancy with an OR of $19.746(95 \% \mathrm{Cl} 1.926-202.456)$ which means mothers who did not receive breast milk counseling during the ANC has 19 times chance for PIM compared to mothers who received breast milk counseling during ANC. The use of "Dialogue" in the concept of $10 \mathrm{~T}$ in the ANC needs to be effective to discuss the preparation of lactation. The suggestion for Health Center, Sewon, Yogyakarta is to give advice to health workers in the working area of the Health Center Sewon to improve breastfeeding counseling during ANC by providing information on Early Breastfeeding Initiation, Exclusive Breastfeeding, and Growth Spurt to reduce the Perceptions of Insufficient Milk Supply. 


\section{REFERENCES}

1. WHO/UNICEF. Baby-Friendly Hospital Initiative Revised Updated and Expanded for Integrated Care Section 3 Breastfeeding promotion and support in a Baby-Friendly Hospital in a 20-hour course for maternity staff. 2009. 274 p.

2. World Health Organization, UNICEF. Infant and young child feeding counseling: an integrated course. Who [Internet]. 2006;1-265. Available from: http://www.who.int/nutrition/publications/ IYCF_Participants_Manual.pdf

3. Dasar RK. Penyajian Pokok-Pokok Hasil Riset Kesehatan Dasar 2013. 2013;

4. DiFrisco E, Goodman KE, Budin WC, Lilienthal MW, Kleinman A, Holmes B. Factors Associated With Exclusive Breastfeeding 2 to 4 Weeks Following Discharge From a Large, Urban, Academic Medical Center Striving for Baby-Friendly Designation. J Perinat Educ. 2011;20(1):28-35.

5. Huang YY, Lee JT, Huang CM, Gau ML. Factors related to maternal perception of milk supply while in the hospital. J Nurs Res. 2009;17(3):179-88.

6. Soemargono F. Kata Pengantar. Archipel. 1977;13(1):15-20.

7. Achadi EL, Hansell MJ, Sloan NL, Anderson MA. Women's nutritional status, iron consumption and weight gain during pregnancy in relation to neonatal weight and length in West Java, Indonesia. Int J Gynecol Obstet [Internet]. 1995 Jun;48(Supplement):S103-19. Available from: http://doi.wiley.com/10.1016/00207292\%2895\%2902325-7

8. Gatti L. Maternal Perceptions of Insufficient Milk Supply in Breastfeeding. J Nurs Scholarsh [Internet]. 2008 Dec;40(4):355-63. Available from: http://doi.wiley.com/10.1111/j.15475069.2008.00234.x

9. Kramer S. Micahel KR. the Optimal Duration of Exclusive a Systematic Review. English. 2002;554:63-77.

10. Trisnawati I. Hubungan Status Gizi Ibu Selama Hamil dengan Persepsi Kemampuan Laktasi
(PKL) di Wilayah Puskesmas Poned Karawang Tahun 2010. 2010;1-93.

11. Komalasari. Analisis Faktor-Faktor yang Berhubungan dengan Persepsi Ketidakcukupan ASI pada Ibu yang Memiliki Bayi Umur 0-12 Bulan di Wilayah Kerja Puskesmas Pancoran Mas Kota Depok Tahun 2011. 2012.

12. Fikawati S, Syafiq A. Study on Policy and Implementation of Exclusive and Early Initiation of Breastfeeding in Indonesia. Makara J Heal Res. 2011;14(1):17-24.

13. Palmer S. Recommended dietary allowances, tenth edition. Vol. 44, European Journal of Clinical Nutrition. 1990. 13-21 p.

14. Irawati A, Triwinarto A, dan Irlina RaswaM S. Pengaruh Status Gizi lbu Selama Kehamilan dan Menyusui Terhadap Keberhasilan Pemberian Air Susu Ibu. Pgm. 2003;26(2):10-9.

15. Kac G, Benício MH, Velásquez-Meléndez G, Valente JG, Struchiner CJ. Breastfeeding and postpartum weight retention in a cohort of Brazilian women. Am J Clin Nutr. 2004 Mar 1;79(3):487-93.

16. Prabasiwi A, Fikawati S, Syafiq A. ASI Eksklusif dan Persepsi Ketidakcukupan ASI. Kesmas Natl Public Heal J. 2015;9(3):282.

17. Rikenawaty IR. Universitas Indonesia Universitas Indonesia Jakarta. Fmipa Ui. 2012.

18. Anand R. Infant and Young Child Feeding. IAP Textb Pediatr. 2013;127-127.

19. Nurheti Yuliarti. No Title. I. Rosalina Fiva, editor. Yogyakarta: C.V. ANDI OFFSET; 2010. 119 p.

20. Sandra Fikawati AS. Hubungan antara Menyusui segera (Immediate Breastfeeding) dan pemberian ASI Eksklusif sampai dengan empat bulan. J Kedokt Trisakti. 2003;22(2):47-55.

21. Gangal P, BhagatK, Prabu S, Nair R. Breastcrawl. Unicef. 2007;

22. Dr. Soetjiningsih D. ASI : Petunjuk Untuk Tenaga Kesehatan. I. Dr. Soetjiningsih D, editor. Jakarta: Buku Kedokteran EGC; 2007. 189 p.

23. Sandra Fikawati AS. Penyebab Keberhasilan dan Kegagalan Praktik Pemberian ASI Eksklusif. Kesmas Natl Public Heal J. 2009;4(3):120-31. 